\title{
Recycling of Different Available Organic Wastes through Vermicomposting
}

\author{
S. KARMAKAR ${ }^{*}$, K. BRAHMACHARI ${ }^{\#}$, \\ A. GANGOPADHYAY*, and S. R. CHOUDHURY ${ }^{\#}$ \\ *Dept. of Geology, National Institute of Technology \\ Durgapur - 713209, Burdwan, West Bengal, India \\ "Dept. of Agronomy, Bidhan Chandra Krishi Viswavidyalaya, \\ Mohanpur - 741252, Nadia, West Bengal, India \\ sruti_karmakar@yahoo.co.in
}

Received 29 May 2011; Accepted 5 August 2011

\begin{abstract}
Generation of organic wastes has been increased in an unprecedented rate in India with rapid population expansion, leading to disposal problems. These organic wastes can be converted into valuable wealth by applying vermicomposting technology. Vermicompost which provides macro and micro nutrients to the plants, also reduces pollution by providing a valuable substitute for chemical fertilizers. Present paper deals with vermicomposting of organic wastes from seven different sources and evaluation of nutrient in those vermicomposts following chemical analyses. These seven sources include coconut coir, water hyacinth, mixed materials, cabbage, banana pseudostem, cow dung, and rice husk. Three composting species of earthworms e.g. Eisenia. fetida, Eudrilus. eugeniae, and Perionyx excavatus were chosen for the experiment. Chemical analysis of vermicomposts under study clearly showed that the vermicompost from water hyacinth contained maximum amount of organic $\mathrm{C}$, total $\mathrm{N}$, and total $\mathrm{K}$ though the phosphorous content was maximum in vermicompost from mixed materials. Lowest nutrient content was observed in vermicompost of coconut coir. Vermicomposts from mixed materials, cabbage, banana pseudostem were at per in their chemical properties. It can be concluded that among the seven sources, vermicompost from water hyacinth is best for its nutrient value.
\end{abstract}

Keywords: Organic wastes, Environmental pollution, Waste management, Vermicomposting, Nutrient value of vermicompost, Earthworms.

\section{Introduction}

In our daily life we create a huge amount of wastes which may be biodegradable or nonbiodegradable in nature. Both of them create several problems including health hazards. In India, about 320 million tons of agricultural wastes are generated annually of which vegetable waste alone is in major proportion ${ }^{1}$. The waste from the vegetable market is 
collected and dumped into the municipal land fills, causing a nuisance because of high biodegradability ${ }^{2}$. When these wastes are improperly dumped, it generally pays a lot of threats to air, water, land, vegetable, wildlife, and human beings. Sickness and disease epidemics often occur due to improper disposal and/or ineffective management of sewage, garbage wastes and unwanted substances. Situation is quite similar in rural surroundings comparing urban areas. As human population pressure is usually lower in villages than that of the urban communities, wastes are less in quantity and there is less congestions in rural areas. So, impacts and repercussions are less severe there. Wastes pollute and contaminate both surface and underground water. Thus affect vital aquatic resources.

To save our environment proper management of these wastes is very essential. Different biodegradable wastes (agricultural wastes, municipal solid wastes, animal wastes etc.) can be converted into useful substances by recycling process in agriculture, because they contain different types of plant nutrients.

Organic wastes can be converted into valuable wealth by applying vermicomposting technology. Vermicomposting is the process by which earthworms are used to convert organic wastes into humus like material known as vermicompost which is rich with various essential plant nutrients ${ }^{3}$. According to Kale, et al. ${ }^{4}$ this composting process can convert all such wastes into wealth. This is an environment-friendly technique entailing no pollution whatsoever. Hence vermicomposting is a more sustainable technique for organic waste disposal and it reduces pollution by providing a valuable substitute for chemical fertilizers. Nutrients in earthworm castings are pre-digested and hence are readily soluble in water for uptake by plants. Vermicompost provides macro and micro nutrients to the plants including biologically active substances such as plant growth regulators ${ }^{5}$.

Earthworms are being successfully used for the purpose of treating a wide variety of organic wastes. Large-scale vermiculture operations produce two saleable products, worms and vermicompost. The basic advantage of using earthworms and vermicomposting process is the sustainable management of organic wastes with significant reduction of garbage discharged into the environment.

Present paper deals with vermicomposting of organic wastes from seven different sources and evaluation of nutrient in those vermicomposts following chemical analyses.

\section{Experimental}

Vermicomposting is a simple biotechnological process of composting where certain species of earthworms are used to enhance the process of waste conversion and produce ecofriendly end-products.

This compost was prepared by and collected from Mr. Animesh Mondol, a progressive farmer and an owner of the vermicomposting plant (small-scale agro input industry built with the technical support from Bidhan Chandra Agricultural University) at villageShantinagar, P.O.-Madanpur, Dist-Nadia, West Bengal, India. Vermicompost was prepared by the 'Heap method" . In the present investigation, seven sources of organic wastes e.g. mixed materials (parts of vegetables, peel of fruits, water hyacinth, green weeds, coconut coir etc., $\left.\mathrm{V}_{1}\right)$, parts of cabbage $\left(\mathrm{V}_{2}\right)$, water hyacinth $\left(\mathrm{V}_{3}\right)$, coconut coir $\left(\mathrm{V}_{4}\right)$, cow dung $\left(\mathrm{V}_{5}\right)$, rice husk $\left(\mathrm{V}_{6}\right)$, and banana pseudostem $\left(\mathrm{V}_{7}\right)$ were separately used to prepare vermicomposts. Three composting species of earthworms such as Eisenia. fetida, Eudrilus. eugeniae, and Perionyx excavatus were chosen for the experiment.

Organic wastes were collected from different sources mainly from the agricultural fields and domestic sources. After chopping these wastes into small pieces, cow dung was mixed with these chopped materials in 3:1 ratio and water was sprayed over it. Then this material was covered with polythene and left for decomposition for 15-25 days. Heat was produced by 
microbes for their metabolism. During this period, the cover was opened sometimes for pouring water to the semi decomposed wastes and stirred with stick. In the next step, these semi decomposed wastes were transferred to the vermi-beds for feeding by earthworms. Massive proliferation of earthworms is occurred through their reproduction. This mixed material was covered by jute bag and water was sprinkled frequently over it. The main characteristic of this earthworm used, is that it takes food more than its body weight. The taken food goes into the stomach and breaks down there. After that this food is digested with the help of different enzymes. This worm uses $7-10 \%$ of its taken food for its physical activities and the remaining is released as excreta. These excreta are known as vermicompost.

The nutrient contents of the vermicompost prepared from different sources were analysed. The chemical parameters of vermicomposts such as organic Carbon $(C)$, total Nitrogen $(N)$, Phosphorus $(\mathrm{P})$ and Potassium $(\mathrm{K})$ were determined using the procedure as described by Jackson?

\section{Results and Discussion}

In the present study, vermicomposts were prepared from seven different sources of organic materials following the 'Heap methods' using three most commonly used earthworm species. Heap method was used as it is reported that heap method of vermicomposting is better than pit method $^{6}$. It is clear from the observations that vermicomposts can be produced easily from different organic materials because the process of vermicomposts is easy and feasible in terms of material/cost required. From their studies, Gandhi et al. ${ }^{8}$ indicated that the vermicomposting converts household waste into compost within 30 days, reduces the $\mathrm{C}$ : $\mathrm{N}$ ratio and retains more $\mathrm{N}$ than the traditional methods of preparing composts. Suthar et al. ${ }^{1}$ noticed that the vermicompost has a high nutrient value, increases fertility of soil and maintains soil health.

The nutrient values of different vermicomposts obtained in present study are shown in Table 1. From this table, it is evident that the vermicompost $\mathrm{V}_{3}$ (vermicompost from water hyacinth) shows the maximum values of organic $\mathrm{C}$, total $\mathrm{N}$, and total $\mathrm{K}$. Vermicompost $\mathrm{V}_{1}$ produced from mixed materials exhibit the maximum value of total $\mathrm{P}$. On the other hand, vermicompost prepared from coconut coir contained the lowest nutrient elements. Among the sources, the cabbage, rice husk, banana pseudostem were at per in their chemical properties.

Table 1. Percentage of different macronutrients in various vermicomposts under study.

\begin{tabular}{llcccc}
\hline S. No & Organic waste used & $\begin{array}{c}\text { Organic C } \\
(\%)\end{array}$ & $\begin{array}{c}\text { Total } \\
\text { N }(\%)\end{array}$ & $\begin{array}{c}\text { Total } \\
\text { P }(\%)\end{array}$ & $\begin{array}{c}\text { Total } \\
\text { K }(\%)\end{array}$ \\
\hline V1 & Mixed materials & 11.98 & 1.28 & 2.13 & 0.92 \\
V2 & Parts of cabage & 10.78 & 1.13 & 2.02 & 0.98 \\
V3 & Water hyacinth & 13.02 & 1.34 & 2.09 & 1.01 \\
V4 & Coconut coir & 9.03 & 0.92 & 1.74 & 0.68 \\
V5 & Cow dung & 9.20 & 0.98 & 1.78 & 0.97 \\
V6 & Rice husk & 9.94 & 1.04 & 1.91 & 0.90 \\
V7 & Banana pseudostem & 11.88 & 1.20 & 1.97 & 0.93 \\
\hline
\end{tabular}

Comparative analysis (percentage value) of various nutrients e.g. organic C, total $\mathrm{N}$, total $\mathrm{P}$, and total $\mathrm{K}$, in different vermicopmposts have been depicted visually with bar diagram in Figure 1, Figure 2, Figure 3, and Figure 4 respectively. 


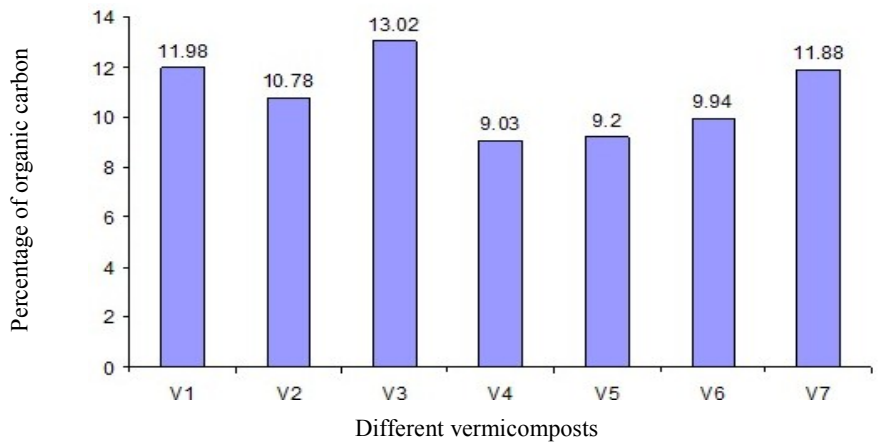

$V_{1^{-}}$Mixed materials, $V_{2}$-Parts of cabbage, $V_{3^{-}}$Water hyacinth, $V_{4^{-}}$Coconut coir, $V_{5^{-}}$Cow dung, $V_{6}$ Rice husk, $V_{7}$-Banana pseudostem.

Figure 1. Percentage of organic $\mathrm{C}$ in different vermicomposts.

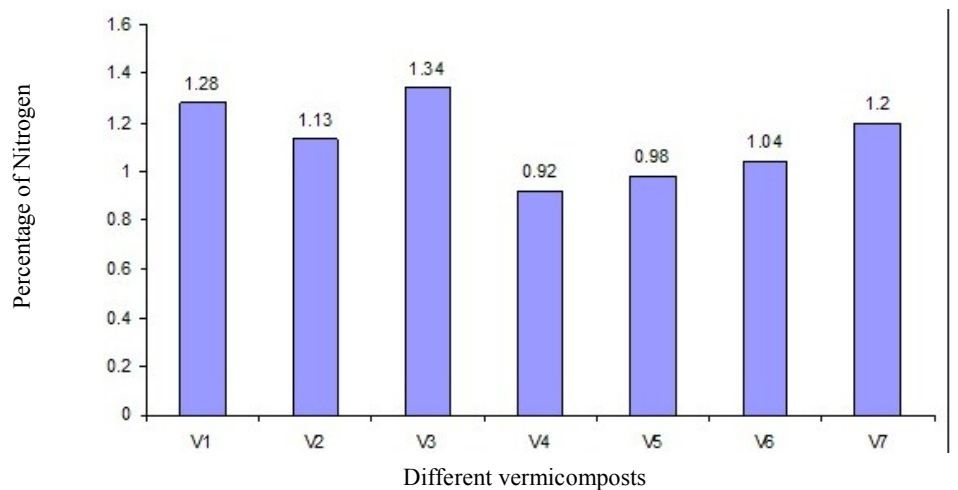

$V_{1^{-}}$Mixed materials, $V_{2}$-Parts of cabbage, $V_{3^{-}}$Water hyacinth, $V_{4^{-}}$Coconut coir, $V_{5^{-}}$Cow dung, $V_{6}$ Rice husk, $V_{7}$-Banana pseudostem.

Figure 2. Percentage of total $\mathrm{N}$ in different vermicomposts.

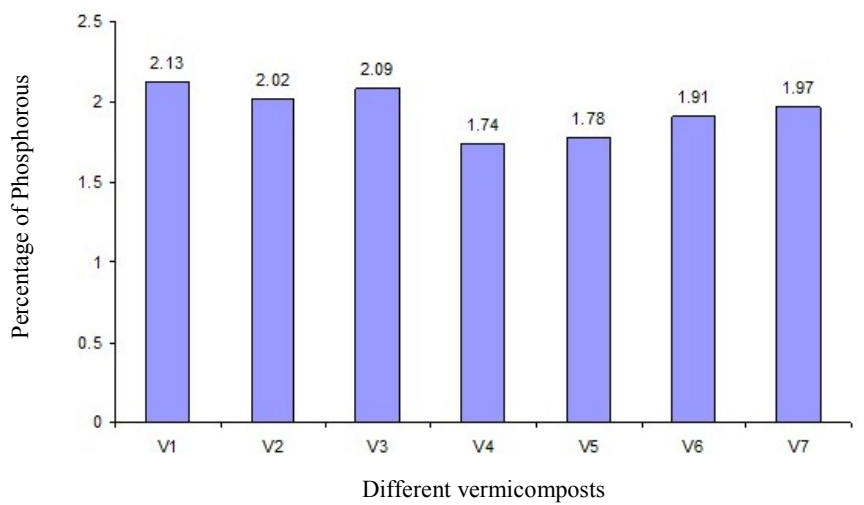

$V_{I^{-}}$Mixed materials, $V_{2}$-Parts of cabbage, $V_{3^{-}}$Water hyacinth, $V_{4^{-}}$Coconut coir, $V_{5^{-}}$Cow dung, $V_{6}$ - Rice husk, $V_{7}$ - Banana pseudostem.

Figure 3. Percentage of total $\mathrm{P}$ in different vermicomposts. 


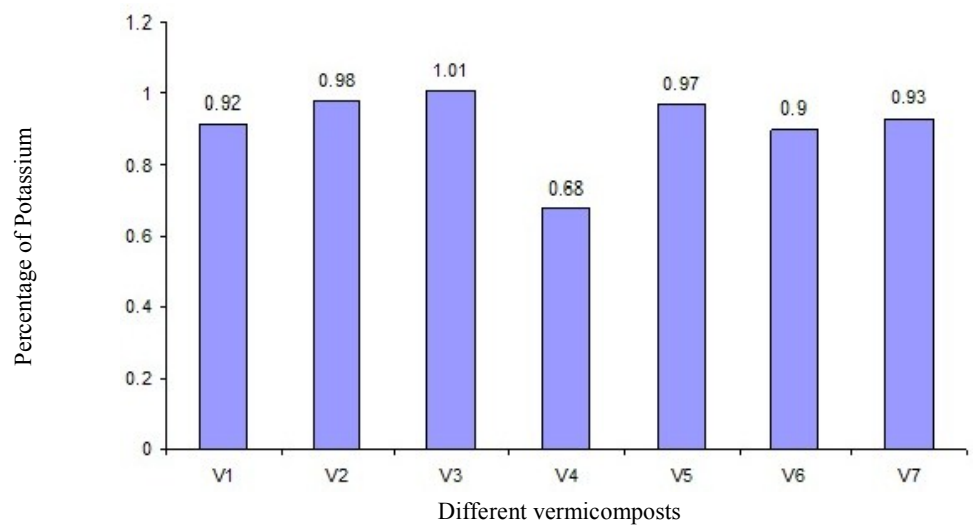

$V_{I^{-}}$Mixed materials, $V_{2}$-Parts of cabbage, $V_{3^{-}}$Water hyacinth, $V_{4^{-}}$Coconut coir, $V_{5^{-}}$Cow dung, $V_{6}-$ Rice husk, $V_{7}$-Banana pseudostem.

Figure 4. Percentage of total $\mathrm{K}$ in different vermicomposts.

Three earthworm specieses namely Eisenia. fetida, Eudrilus. eugeniae, and Perionyx excavatus were used in vermicompost preparation in the study reported here. In this connection, it is worthy to mentioned that Gajalakshmi et al. ${ }^{9}$ assessed the two epigeic species (Eudrilus eugeniae and Perionyx excavatus) and two anecic species (Lampito mauritii and Drawida willsi) of earthworms in terms of efficiency and sustainability of vermicomposting of water hyacinth and cow dung $(6: 1 \mathrm{w} / \mathrm{w})$. Trend observed in their research regarding mass of vermicasts produced per unit time for the given rate of feed input was E. eugeniae $>$ P. excavates $>$ L.mauritii $>$ D. willsi. Similar trends were observed for increase in biomass and number of offspring biomass produced. During studying the yield of vermicompost based on worm densities per litre of digester volume, Gajalakshmi et al. ${ }^{10}$ observed that vermicast yield consistently increased with worm density - from the average of $46.6 \%$ in 50 worm to $93.4 \%$ in 150 worm reactors.

\section{Conclusion}

The results indicate that organic wastes (mixed materials, parts of cabbage, water hyacinth, coconut coir, cow dung, rice husk, banana pseudostem) were successfully processed through vermicomposting technology. It can be concluded that among the seven sources, vermicompost from water hyacinth is best for its nutrient value.

\section{Refferences}

1. Suthar S S, Watts J, Sandhu M, Rana S, Kanwal A, Gupta D and Meena M S, Asian J Microbiol Biotech Envron Sci., 2005, 7, 541-544.

2. Bouallagui H, Torrijos M, Godon J J, Moletta R, Cheikh R B, Touhami Y and Delgenes J P, Biochem Eng J., 2004, 21, 93-197.

3. Benitez E, Nogales R, Elvira C, Masciandaro G and Ceccanti B, Bioresource Tech., 1999, 67, 297-303.

4. Kale R D, Bano K and Krishnamoorthy R V, Pedobiologia., 1982, 23, 419-425.

5. Atiyeh R M, Lee S, Edwards C A, Arancon N Q and Metzger J D, Bioresource Technol., 2002, 84, 7-14.

6. Sunitha ND, Giraddi RS, Kulkarni KA and Lingappa S, Karnataka J Agrl Sci., 1997, 10(4), 987-990. 
806 S. KARMAKAR et al.

7. Jackson M L, Soil chemical analysis ( $2^{\text {nd }}$ Ed. $)$, Prentice Hall of India Ltd., New Delhi, 1973, 485.

8. Gandhi M, Sangwan V, Kapoor K K and Dilbaghi N, Environ Eco., 1997, 15(2), 432-434.

9. Gajalakshmi S, Ramasamy E V and Abbasi S A, Biores Tech., 2000, 76, 171-181.

10. Gajalakshmi S, Ramasamy E V and Abbasi S A, Biores Tech., 2001, 80, 131-135. 


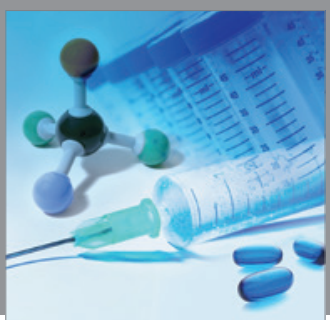

International Journal of

Medicinal Chemistry

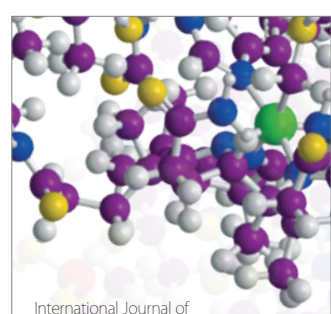

Carbohydrate Chemistry

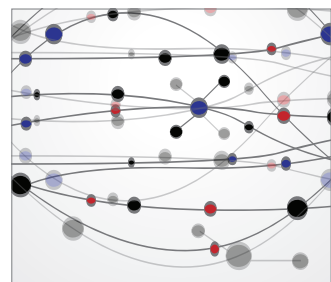

The Scientific World Journal
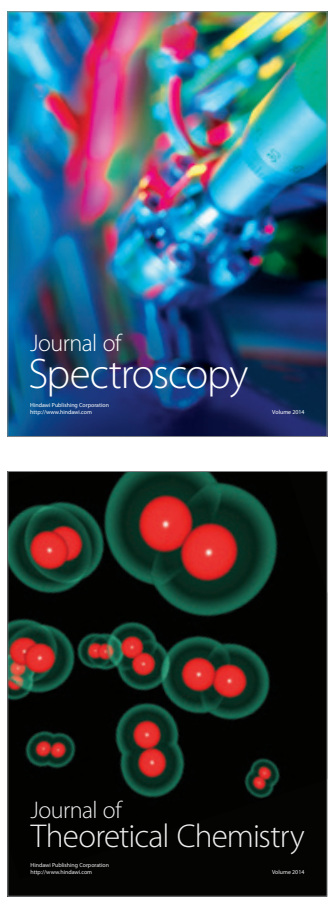
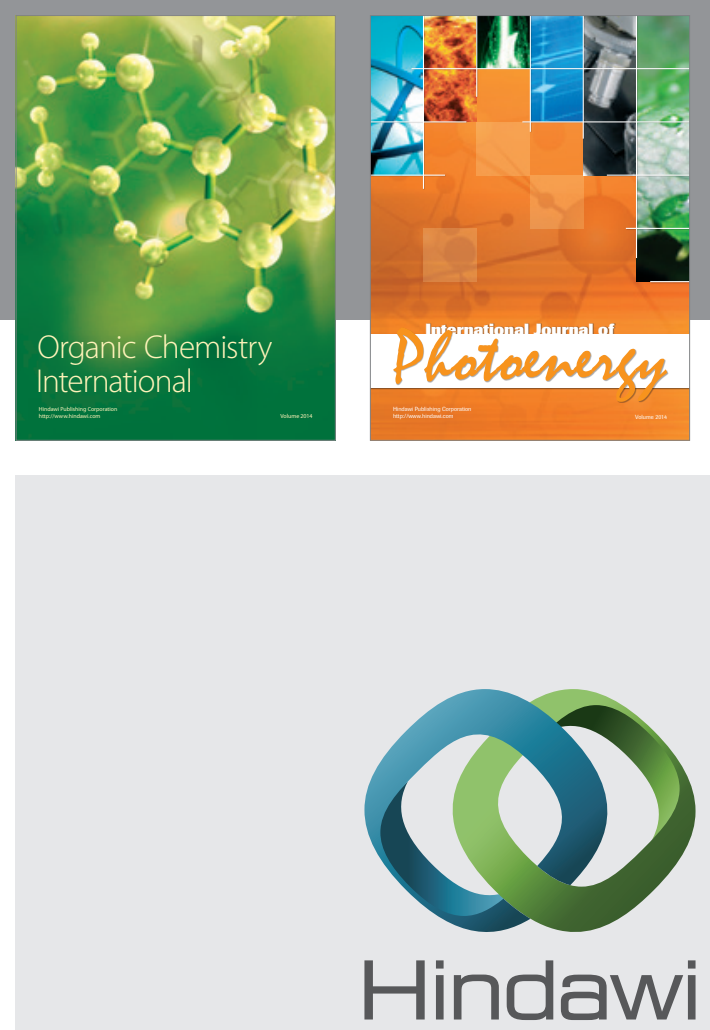

Submit your manuscripts at

http://www.hindawi.com
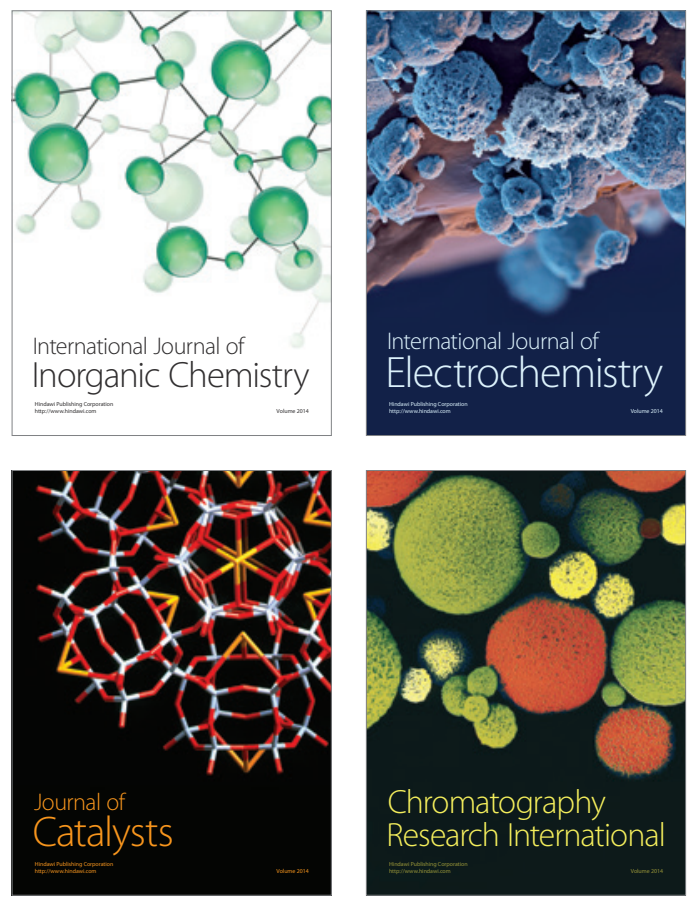
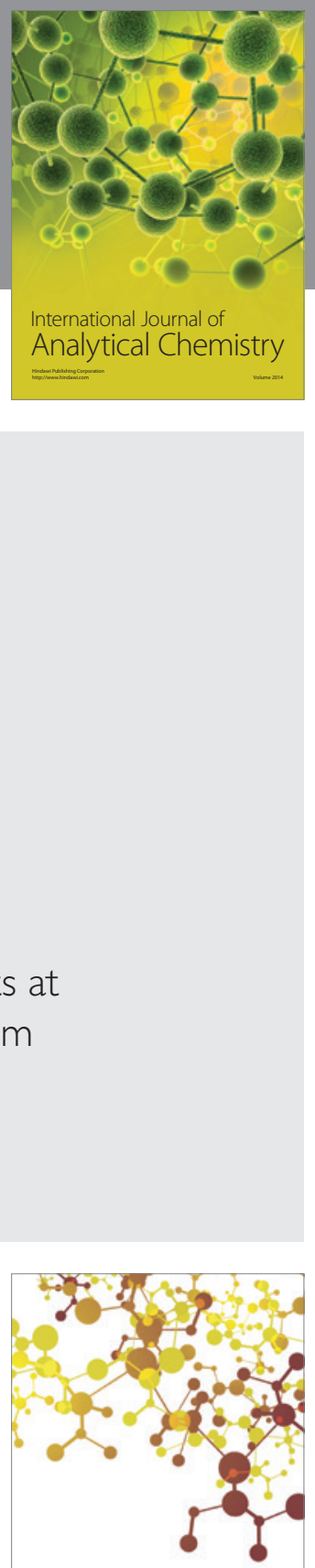

Journal of

Applied Chemistry
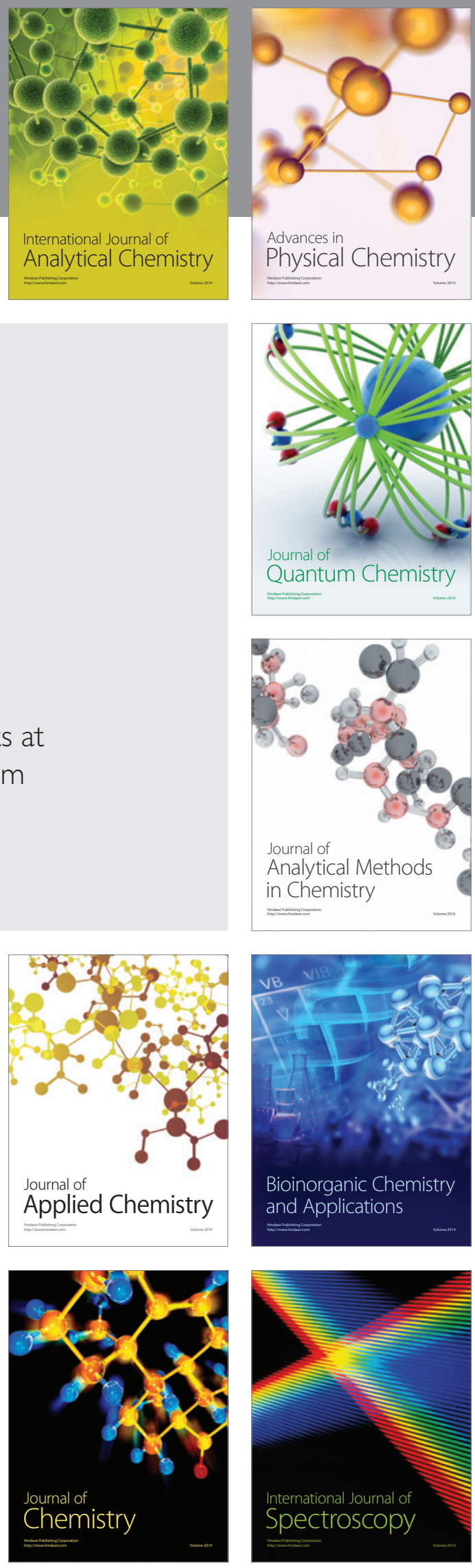